University of Wollongong

Research Online

Faculty of Social Sciences - Papers (Archive) Faculty of Arts, Social Sciences \& Humanities

$1-1-2019$

'Those are the things that we need to be talking about': the impact of learning about the history of racial oppression during Ghana study abroad

Katarzyna J. Olcon

University of Wollongong, kolcon@uow.edu.au

Rose Pulliam

Texas State University

Dorie Gilbert

Prairie View A\&M University

Follow this and additional works at: https://ro.uow.edu.au/sspapers

Part of the Education Commons, and the Social and Behavioral Sciences Commons

Research Online is the open access institutional repository for the University of Wollongong. For further information contact the UOW Library: research-pubs@uow.edu.au 


\title{
'Those are the things that we need to be talking about': the impact of learning about the history of racial oppression during Ghana study abroad
}

\author{
Abstract \\ This article examined what U.S. college students who participated in a Ghana study abroad program \\ learned about the history of racial oppression and the meaning-making that resulted from that knowledge. \\ Based on inductive thematic analysis of a variety of qualitative data sources, four themes were identified: \\ (1) the suffering and resilience of African and African descent people; (2) 'it's still happening today'; (3) \\ 'you don't learn about that in school'; and (4) remembrance, equity, and healing. Students expressed \\ frustration with the U.S. education system which 'breezes through' the topics of slavery and colonialism. \\ As connections between the past and present racial oppression in the United States and globally were \\ recognized, students yearned for a forthright education and dialogue about racism as a first step toward \\ acknowledging historical trauma and creating a racially equitable society. More explicit education related \\ to slavery and colonialism and their current repercussions is needed.

\section{Disciplines \\ Education | Social and Behavioral Sciences}

\section{Publication Details} \\ Olcon, K., Pulliam, R. M. \& Gilbert, D. J. (2019). 'Those are the things that we need to be talking about': the \\ impact of learning about the history of racial oppression during Ghana study abroad. Race Ethnicity and \\ Education, Online First 1-18.
}


'Those are the things that we need to be talking about':

the impact of learning about the history of racial oppression during

Ghana study abroad

Katarzyna Olcoń, University of Wollongong ${ }^{1}$

Rose M. Pulliam, Texas State University

Dorie J. Gilbert, Prairie View A\&M University

Corresponding author: Katarzyna Olcoń, PhD, Lecturer, Social Work, Faculty of Social

Sciences, University of Wollongong, South Western Sydney Campus, 33 Moore St, Liverpool, NSW 2170 Australia. Email: kolcon@uow.edu.au.

\footnotetext{
${ }^{1}$ Research conducted while the author was affiliated with The University of Texas at Austin Steve Hicks School of Social Work.
} 


\begin{abstract}
This article examined what U.S. college students who participated in a Ghana study abroad program learned about the history of racial oppression and the meaning-making that resulted from that knowledge. Based on inductive thematic analysis of a variety of qualitative data sources, four themes were identified: (1) the suffering and resilience of African and African descent people; (2) 'it's still happening today'; (3) 'you don't learn about that in school'; and (4) remembrance, equity, and healing. Students expressed frustration with the U.S. education system which 'breezes through' the topics of slavery and colonialism. As connections between the past and present racial oppression in the United States and globally were recognized, students yearned for a forthright education and dialogue about racism as a first step toward acknowledging historical trauma and creating a racially equitable society. More explicit education related to slavery and colonialism and their current repercussions is needed.
\end{abstract}

Keywords: racial oppression, slavery, anti-racism pedagogy, student learning, U.S. history education, study abroad 
'Those are the things that we need to be talking about': the impact of learning about the history of racial oppression during Ghana study abroad

\section{Introduction}

'History is not everything, but it is a starting point. History is a clock that people use to tell their political and cultural time of day. It is a compass they use to find themselves on the map of human geography. It tells them where they are, but more importantly, what they must be.'

- John Henrik Clarke

It's a hot and humid day in Accra, similar to many others. Students sit in a circle outside by the hotel's pool. They look tired and deep in thought. The program is getting close to the end. 'What have you learned in the last few days?' - the program instructor asks. After a moment of heavy silence, a White U.S. college senior responds: 'I always thought slavery was a thing of the past, I thought it does not affect anyone in the U.S. any more. I learned that it still impacts people. It was much worse than I thought'.

This moment took place on a U.S. study abroad program in Ghana and sheds light on the deep disconnect of students' knowledge, particularly those who are White, of slavery's treacherous imprint on history and the current realities of U.S. Blacks. The words of Michael Reisch written thirty years ago, that we live in 'a ahistorical, almost anti-historical culture' (1988, p. 3) continue to ring true today, and certainly even more so when referring to the tragic history such as colonialism and slavery. Several phenomena in the post-civil rights era have functioned to suppress the topic of racial oppression. Racism has come to be viewed as a matter of individual moral failure, an intentional and conscious act based on individual prejudices, as opposed to a systemic issue (DiAngelo, 2018). As Adams et al. (2008, 349) explained: 'An unintended consequence of this portrayal is to reproduce a narrow construction of racism as something that does not require energetic measures to combat.' Moreover, the colorblindness 
ideology and the claims of having entered a 'post racial' era 'protect racism by making it invisible' (Kandaswamy 2007, 7). Finally, the popular multiculturalism discourse focuses on celebrating cultural differences without any critical analysis of power structures (Kandaswamy 2007), therefore further perpetuating the system of racial inequality.

\section{Gaps in U.S. education on history of racial oppression}

Authors have criticized the mainstream U.S. educational system for its shortcomings in teaching about U.S. history, including the limited acknowledgment of past and present racial injustices, lack of explicit exploration of institutional racism, and presenting racism as a solved problem (George and Williams 2018; Grant 2011; King 2016). For example, King (2016, 1305) pointed to the 'selective inclusion of historical narratives through biases and omissions that distort the historical and social reality of minority groups.' One of the reasons for this distortion is the Eurocentric approach that presents a one-dimensional view on the foundation and growth of the United States as a country (Kolchin 1998; Loewen 2007; Olwell 2001). Based on a survey of twelve leading U.S. history textbooks, Loewen (2007) concluded in the seminal book, Lies my teacher told me: everything your American history textbook got wrong, that the texts were written in a bland and simplistic style that minimized and often deceived the reader about historical controversies such as the slave trade. Similarly, in a comparison of how slavery was presented in the U.S. and Brazilian secondary history textbooks, Khan (2013) found that slavery was framed in the United States as an example of American progress toward the ideals described in the founding documents such as the U.S. Constitution. Discussion on the legacy of slavery, where the textbook authors would have 'connected slavery with the enduring issues of society' (Khan 2013, 75), was mostly absent in both the U.S. and the Brazilian textbooks. Moreover, a 
recent report by the Southern Poverty Law Center (SPLC 2018), Teaching the hard history of American slavery, shows that the history of slavery is not adequately taught in school, educators lack the knowledge and skills to teach the topic effectively, textbooks do not provide a comprehensive coverage of the topic, and states' legislations fails to set appropriate content standards. In result, 'high school seniors struggle on even the most basic questions about American enslavement of Africans' (SPLC 2018, 9).

Given these gaps in high school history education, most students enter college without knowing much about the history of racial oppression (Olwell 2001). Despite this, the number of studies that explore undergraduate or graduate students' learning and understanding of the history of racial oppression is very limited (e.g. George and Williams 2018; King 2016). For example, George and Williams $(2018,320)$ found that college students who were introduced in a sociology course to the horrific 1918 lynching of 13 people in South Georgia were 'indignant that they had no knowledge about the long legacy of lynching and racism that is part of the region's history.' 'How do we not know about this?!?' (George and Williams 2018, 320) is how one student summarized the shock about this 'lost history' (320).

\section{Pedagogical approaches and challenges}

In addition to the significant content deficiencies in the U.S. history curricula, pedagogical strategies can be challenging. Slavery and other forms of racial oppression are subjects that provokes uncomfortable feelings among both teachers and students (Jay and Lyerly 2016; Smith 1998; Tatum 1999). In Understanding and teaching American slavery, Jay and Lyerly (2016) explain that teachers often feel scared and uncertain about addressing the topic and may teach it ineffectively or avoid it altogether. Students, in turn, can become overwhelmed by a variety of 
feelings, such as shame, anger, guilt, denial, and embarrassment if the topic is not adequately facilitated (Jay and Lyerly 2016; Tatum 1999). Given these difficulties, authors agree on the importance of improving the way history of slavery is taught in schools because '...Black-White race relations in the United States have been forever shaped by slavery and its social, psychological, and economic legacy' (Tatum 1999, 1), and the silence on the topic further perpetuates the oppressive racial dynamics (Triouillot 1995).

Critical race theory (Bell 1992) is particularly helpful in understanding and dismantling the barriers placed on history education that exposes racial oppression (Ladson-Billings 1998, 2005; Tate 1997). Maintained by members of the dominant culture, the mainstream discourse does not acknowledge the version of history as experienced by ethnic and racial minorities (Delgado and Stefancic 2001). Critical race pedagogy (Ledesma and Calderón 2015) and critical race curriculum (Yosso 2002) challenge the dominant discourses on race and racism and point to the ultimate goal 'to unsettle and center highly charged histories and contemporary realities that the majority dismiss with narratives of colorblindness, meritocracy, or postracialism' (Ledesma and Calderón 2015, 208).

Finally, there has been an increased interest in study abroad as a valuable aspect of higher education (e.g., Levine 2009; Marx and Pray 2011). The majority of the studies, however, do not address teaching and learning about racial oppression and focus instead on student outcomes such as cultural adaptability (Mapp 2012), acceptance of differences (Levine 2009), cultural humility, (Schuldberg et al. 2012), or intercultural sensitivity (Boateng and Thompson 2013). This lack of focus on race raises the concern about the potential risks of study abroad programs which 'may be a haphazard experience which results in little more than cultural tourism, benevolent helping or paternalistic engagement' (Das and Anand 2014, 110). Cramer, Ryosho, 
and Nguyen $(2013,9)$ recommended that in order to avoid the 'circus-like quality' of cultural immersions, students should spend time and genuinely engage with the communities they visit and learn from. VeLure Roholt and Fisher (2013) additionally suggested that study abroad programs should be framed within decolonizing pedagogy that raises students' awareness about issues of power, colonialism, and imperialism and leads to a critical reflection and dialogue.

The present study thus aimed to answer the following research questions: (1) What did U.S. college students learn about the history of racial oppression during a study abroad program in Ghana?; (2) How was their learning experience different from their education in the United States?; and (3) What meaning did the students make of this new historical understanding?

\section{Methods}

As part of a larger research project, this study is based on data collected from students who participated in a three-week summer Ghana study abroad program, offered collaboratively by two U.S. southern universities in 2016 and 2017. The IRB approval was granted by institutional review boards for both universities. No compensation was offered for the participation in the study. Students were free to decline to participate in the study without impact on their course grade.

Designed and taught by two African American professors, the study abroad curriculum focused on the topic of human rights and social justice and included classroom-based and service learning activities; visits to local museums (including the W.E.B Du Bois Center), art markets and social service agencies; immersion in the life of a local village; and excursions. Ghana offered a unique context for learning about race and racism as it was one of the major ports for transatlantic slave trade, and students had the opportunity to visit the 'slave castles' in the towns of Elmina and Cape Coast which served as holding places for the captives who were later forced 
onto ships to the Americas and elsewhere. Homegoing, a historical novel by Yaa Gyasi, which describes the impact of the transatlantic slave trade down several generations was introduced in the second year of the program. The stories of the captives in the slave castles and their subsequent experiences in the United States provided the background for students prior to the trip and allowed for a personal and emotional connection to the plight of enslaved generations of Black people.

\section{Description of sample}

Over the two years, 32 students enrolled in the program, and 19 consented to participate in the study. The data consists of ethnographic observations in Ghana of the 19 students, written journals of 17 of the students (two chose not to share their journals), and 17 student interviews conducted in the United States two to three months after the end of the program (two students could not be reached). Sixteen of the 19 participants were women, two were men, and one was gender non-binary. In terms of race and ethnicity, eight students were White, eight were Latino/a, two were Black, and one was Asian American. Student ages ranged from 20 to 46, with 26 as average. Fifteen of the students were social work majors, and the other four majors included international relations, drama and theater for youth and communities, student affairs in higher education, and dementia and aging studies. Thirteen students were undergraduate and six were graduate. Five students had never traveled abroad before, seven had some previous international exposure, e.g. brief overseas holidays, and another seven had extensive international experiences including having lived and studied abroad. None of the students had been to Africa before. 


\section{Data collection}

The study employed a variety of data collection methods: ethnographic observations, participants' written reflections, and in-depth interviews. Data was collected by the first author, a Ph.D. student of social work at the time, who identifies as White and an immigrant to the United States from Poland. The second author is an African American professor of social work who directed the Ghana program in the two years of data collection. The third author, also an African American professor of social work, established and directed the Ghana program over several years prior.

Ethnographic observations (Creswell 2013; Lofland et al. 2006) were conducted by the first author in Ghana during the immersion program in years 2016 and 2017 with two cohorts of students for a total of seven weeks. The purpose of the ethnographic observations was to document student experiences, discussions and interactions during program activities, important events, daily group meetings, and debriefing circles. The first author became a participant observer (Creswell 2013) of all of the program activities, and took extensive fieldnotes documenting important events, group discussions, and interactions. For example, students had daily group meetings to reflect on important issues or events, and to share their experiences and feelings. By participating in these meetings, the researcher was able to document the students' immediate reactions, and later compare those with other sources of data, specifically students' written self-reflections and interviews. The ethnographic fieldnote-writing process was guided by the work of Emerson, Fretz, and Shaw (2011) and included a detailed description and a reflection component for each entry. The fieldnotes were recorded during activities and events, as well as at the end of the day, and they totaled over one hundred single-spaced pages recorded in a Word document. 
Written journals, in which students reflected on their experiences and impressions while in Ghana, were also analyzed. As part of the study abroad course, each student was required to submit a total of 17 written reflections: one prior to traveling to Ghana, 15 while in Ghana, and one upon return from Ghana. While in Ghana students were asked to: 'Reflect on something that you experienced or learned today: What was it? How do you feel about it? Anything surprised you?' These questions allowed students to write about anything that they found important without guiding them in any direction.

Finally, individual, in-depth interviews were conducted by the first author 60-90 days after return from Ghana. A semi-structured interview guide was designed to elicit students’ descriptions of their learning about race and racism that took place as a result of the program in Ghana, and any significant experiences that impacted their learning. Some of the questions on the interview guide included: 'What were your experiences in terms of learning about race and racism while in Ghana?' 'What, if any, impact did the learning about the history of slavery and colonization have on you?' and 'How does what you experienced or learned about race impact you now that you are back in the United States?' Probes were constructed to elicit detailed examples from students. The interviews ranged from 47 minutes to 1 hour and 34 minutes, with an average length of 68 minutes. They were audio-recorded, transcribed, and returned to study participants for comments and corrections. In addition, exhaustive fieldnotes were recorded following each interview.

\section{Data analysis}

Data were analyzed using an inductive thematic approach (Braun and Clarke 2006; Guest, MacQueen, and Namey 2012) and managed through QSR NVivo 11 software (Bazeley 2007). 
Thematic analysis is theoretically flexible, interpretive, and data driven, which allowed for uncovering the thoughts, perceptions, and feelings of the study participants (Grbich 2012; LeCompte and Schensul 1999). The first author developed a codebook after a comprehensive reading of half of the data, and the team members evaluated and revised it collaboratively. The final codebook consisted of ten codes including: 'experiences in the slave castles,' 'emotional learning about history,' and 'barriers to authentic history education,' and 'need for change.' Each data source was coded by the first author and reviewed by a team member to assess the application of codes to segments of text. The purpose of this evaluation was not to estimate intercoder reliability, but rather to 'add breadth and depth to the analysis' by including multiple interpretations (Tuckett 2005, 36). Saturation, defined as 'the point when no new information is obtained from additional qualitative data' (Kerr, Nixon, and Wild 2010, 272), occurred after the analysis of the ethnographic fieldnotes and six interviews. Additional strategies applied to ensure the rigor and credibility of the analysis included data triangulation, a reflective diary to enhance researcher's reflexivity (Meyrick 2006), and member checking (Lincoln and Guba 1985). Six participants responded to the request for feedback, and they all validated the study's results.

\section{Results}

We identified four major themes pertinent to the students' learning about racial oppression while in Ghana: (1) the suffering and resilience of African and African descent people; (2) 'it's still happening today'; (3) 'you don't learn about that in school'; and (4) remembrance, equity, and healing. We use descriptions and quotations from the students to exemplify how these themes manifested in the data. Each student's race/ethnicity is identified to acknowledge potential differences in students' perspectives based on their background. 


\section{The suffering and resilience of African and African descent people}

During the study abroad experience, students were exposed to the traumatic history of African and African descent people, especially the impact of the European colonialization and the transatlantic slave trade. Referring to the visit to the slave castles as one of the most moving and transformative moments during their time in Ghana, students talked about starting to understand the history from a different perspective. Non-Black students in particular developed an empathy and a new appreciation for the circumstances that African and African descent people have been facing. Students also had the opportunity to learn about Black liberation, resilience, and empowerment given that Ghana was the first country in Sub-Saharan Africa to gain independence from the European colonizers, and it became a symbol of the fight for freedom.

The vivid experience of stepping into the slave castles and the resulting disbelief, sadness, and anger played a significantly role in students' learning about racial oppression and injustice. The researcher's ethnographic fieldnotes taken on the day of the visit to the slave castles provide a glimpse of the experiences and the immediate impact of the visit on students:

By 9am we arrived in the Cape Coast Castle.... The day was very hot and humid. Combined with the whiteness of the castles' walls, the strong sunlight was blinding us. When we went down to the dungeons, the air became so stuffed, at moments almost unbearable. Most of the time we had to walk on uneven surfaces in complete darkness. The first dungeon was perhaps the hardest to enter. We had to adjust from the outside's sunlight to complete darkness, walking very carefully on dirt and rocks and trying to leave enough space for others. I could sense some students struggled with walking. As soon as we entered the first dungeon, some students started to cry.

Students were shocked to realize the magnitude of the slave trade and the inhumane conditions that the millions of the enslaved Africans had to suffer. Describing this horrific treatment of African and African descent people since the European colonization and the subsequent transatlantic slave trade, this is how one White student summarized it in his journal:

'Dehumanization, devaluation, and demonization'. 
Stepping into the castles, standing in the dungeons, seeing the 'door of no return,' and all other aspects of experiencing and 'feeling' the place, significantly enhanced students' ability to understand the extent of the suffering that took place in those spaces. Students were deeply moved and described the intense emotions they experienced in the castles and how they were overwhelmed by the energy of the place. A White student summarized the emotions she felt on that day in her journal in the following way:

I was imagining I would have feelings of anger and sadness while visiting. I was made aware of the basic elements of what went on, so I was expecting to see horrors and atrocities, but I was not prepared for the magnitude of how I would feel, and what I would experience, despite setting my bar high for these factors. I was angered, tearful, and generally overwhelmed and dumbfounded by the experience.

Everyone was silent and seemed to be deep in thought, hurting, and angered. Independently of the racial background, many students cried at various points of the tours, in the following debriefing circles, and some for a few days afterwards. The emotional impact the castles had on students could also be observed during the interviews conducted a few months after the trip when the topic of the slave castles came up, students would become serious and thoughtful, they frequently paused as they spoke, and some were teary eyed. The emotions students experienced helped them better comprehend the magnitude of the trauma inflicted by racism and slavery in the United States. As one Latina student put it:

At the moment, when we were learning about it, it was really emotional, in a way, just like how, crazy it is to think that slavery didn't even end that long ago. And just how cruel people could be.... But it did help me understand more of the suffering of African Americans and the history of Africa.

In the face of such immensity of human suffering and injustice, the theme of resilience, courage, and empowerment of Black people was brought up by some students. A Latina student wrote in her journal about how much she admired the 'resilience, courage, and determination of African Americans', who despite the centuries of violence and suffering 'keep standing up with 
their heads high and proud to be where they are'. A Black student shared in a debriefing circle that she was surprised to find herself less angry and emotional than she expected in the slave castles. Instead she experienced a calm recognition and happiness about her ancestors' strength to have survived the atrocities and to 'continue to thrive'. In her journal, she elaborated:

All of this torture, rape, violence, and hatred and WE ARE STILL HERE! How many feelings and doubts dissipated and this appreciation and absolute awe for the African heritage, that I am honored to be a part of and engage in its legacy, overtook me.

This Black student was able to find personal meaning and strength in learning about the resilience of her ancestors. Many White students, on the other hand, exhibited guilt, shame, and defensiveness learning about this history and making a connection to their ancestors. Despite these feelings, the majority of them wanted to learn more about slavery and take an active role in making this history known to others.

\section{'It's still happening today'}

In addition to expanding their knowledge of the history of racial oppression, students started to develop an understanding of the present-day consequences of slavery and colonialism. Except for the two Black student participants who had a prior understanding, the majority of the other students talked about the realization that Black people continue to suffer from racial oppression, e.g., in form of institutional racism in the United States and the continuous exploitation of resources in Africa by foreign powers. Students also brought up the ongoing psychological impact of the racial atrocities for all parties involved. The reality of historical trauma as well as the continuous racial oppression, which many students were not concerned about prior to going to Ghana, suddenly became very evident and disturbing. 
For the first time, many students started to make connections between the injustice that was inflicted upon African and African descent people historically and the current oppression of African Americans in the United States. Some students, particularly those of Latino descent, made comparisons to other racial and ethnic minority groups in the United States. Students began to build an understanding of the present-day consequences of the past race-based violations, including wealth inequalities, health and educational disparities, mass incarnations of Black men, and others. An Asian American student summarized this continuous form of oppression during the interview in the following way: 'It's still happening today. The prison system is a source of enslavement'. A very vivid representation of an ongoing systematic racism was shared in the debriefing circle following the visit to the slave castles. A Black student described her experience of being stopped by the police for not having a seatbelt on. She was pulled out of the car by her hair, pepper sprayed, assaulted, and arrested. Memories of those experiences came back to her during the tour of the slave castles: 'I had flashback of being in a tiny room alone, not knowing why I was there, not knowing how long I would be there, not knowing what was going to happen.' This student's story was a first-hand testimony in the group of how racism is still a part of everyday life of racial minority individuals.

Given this and many similar moments of consciousness raising related to race and racism, students reported that they started to pay more attention to the news which involved race-related dynamics. One White student described how shortly after her return to the United States there was another incident of a Black man being shot by the police. She explained how she reacted to this news differently than ever before:

I heard about it immediately [after] coming back from Ghana, and I was just so angry.... I saw it in a completely new perspective, how it is an issue. And just because I'm not personally affected by it, it's still an issue. So, I think it's definitely opened my eyes to the injustice in the United States. 
Previously oblivious to the police brutality against African Americans because it did not personally affect her, this student started to recognize the injustice committed against racial minorities in the United States and feel angered by it.

In addition to recognizing the current structural arrangements which perpetuate the historical racial atrocities, some students also talked about the emotional repercussions of this history. Students believed that dehumanizing practices such as slavery cannot remain unacknowledged because, despite the passage of time, they carry an unresolved pain that impacts the entire nation. One White student explained it in the following way:

I had kind of the attitude of respecting people's pain of slavery, but it was a thing of the past... When I went to the slave castles, I realized how much pain, how much atrocity, how much injustice. Like so deep, not like just surface level injustice, but a real, that there's no way that, that pain and injustice couldn't roll into America, into today.

Students were able to make the connections between historical oppression and the current institutional racism and the disparities in the United States. History thus became much closer to students, and they recognized its vast impact on the present-day realities people live in the United States and across the world.

\section{'You don't learn about that in school'}

Stepping into the slave castles and facing the consequences of the genocide that took place as a result of European colonization and the transatlantic slave trade, students realized how little knowledge and awareness they had of this tragic history. These experiences disrupted some students' entire worldview and the educational foundation of what they seemed to have known about the world and the U.S. history up until that point. Students expressed frustration and disappointment with the U.S. education system which they described as not teaching history in 
an authentic way. They talked about the minimal information about racial oppression and Black history, in general, included in history textbooks and the rush with which their teachers covered related topics throughout their education.

Students talked about how little they learned about history of colonialism and slavery during all the years of their education in the United States. They used terms such as 'breezed over' and 'hidden' when referring to the education about racial oppression and anti-Black sentiment in the United States. They expressed anger and disappointment with the education they received in the United States in terms of teaching them about these important historical events. A White student described in her journal the frustration with the history education she received in the United States in the following way:

I am furious with the way that the public-school system educates children about the transatlantic slave trade. After visiting the slave castles, I am angry that the severity and impact of this isn't emphasized to convey the depth in schools. Looking back on my secondary school education, it is as if teachers breezed over the chapter in order to avoid dialogue. This made me even more mad to think about because it allowed those of European decent to not have to think about the consequences while those of African descent weren't given the chance to fully learn about their ancestors.

Some students felt cheated by the U.S. education system, specifically because the textbooks minimally covered the content and the teachers offered little opportunity to discuss race-related topics. Two Latina students expressed a similar realization of their knowledge gaps: 'I learned more during this one month in Ghana than during all my years of schooling in the U.S', and 'Visiting the castles has filled in some gaps visible in history books and my entire American history education.' During a debriefing circle in Ghana, a White student ironically summarized the way she was taught about slavery in the United States: 'Slavery was bad. Abraham Lincoln ended it. We are good now.' 
Students were also not aware of other critical historical information. For example, several White students admitted that they had never heard of W.E.B. Du Bois, the existence of the Ashanti kingdom, and that Christianity was spread across Africa as a result of colonization. Students were also shocked to realize the recency of the colonial rule in Africa, given that Ghana became the first country in Sub-Saharan Africa to gain independence from Great Britain in 1957. The chronological proximity of these events and being physically present on the African continent brought the oppression and exploitation of the African and African descent people so much closer to students. The very few students who had more awareness and knowledge about these issues, all of whom were either Black or Latino, stated that they had to seek out this type of knowledge on their own. A Latino student emphasized the frustration with the education system: 'I had to go out of my way to learn about those. It wasn't taught to me, specifically for slavery.'

All students agreed that the knowledge they gained in Ghana, although essential for any American, was not offered to them in the regular education system. The education system in the United States left them with significant gaps in knowledge and understanding of both historical and present racial oppression.

\section{Remembrance, equity, and healing}

Given the new historical understanding they gained in Ghana, students yearned for more dialogue to recognize and remember the tragic history of racial oppression against African and African descent people and eradicate any ongoing racial inequities. Some students talked about the need for 'racial healing' with the hope for improving cross-racial relations. Students additionally started to list reasons for why the authentic U.S. history and ongoing racial injustice is 'breezed over' in the U.S. education and avoided in the national discourse. Accurate history 
education and 'telling the truth', open dialogue about past and present racial oppression, and anti-racism advocacy were some of the steps students recommended for creating racial equity.

Students discussed the different barriers that they believed have stifled the history education in the United States. Some students talked about the maintenance of status quo and how the dominant White class continues to benefit from the current racial inequalities. One White student believed that the control of the economic and political systems by Whites is the root cause of racial oppression: 'It starts with power, and the people in power were Europeans, and of course they want to maintain that power structure and kinda keep it in the family, quote unquote.' Others wondered whether the limited teaching of the painful U.S. history in schools and universities is a representation of the broader national attitude toward shameful historical truths, as something no longer relevant and something to forget about. An Asian American student summarized this in the following way:

I think we're ashamed of what we did.... just like part of our history that's really shameful. We learn about Nazi Germany cause that's not us. But people don't want to admit that they did so many terrible things as a country. And I think that can contribute to what's going on right now, cause I see a lot of White supremist or nationalists. They' re like: 'why are you upset over something that happened two hundred years ago?'... So, I just feel like you don't realize the magnitude of it, like they don't teach it enough.... But when you see the slave castles, you see how many people actually made it, and how many people were killed.... It's like really morbid, and it's not something that people will admit their ancestors did.

In addition to facing the shame, addressing the disturbing history would also require the nation to take an accountability for what happened. Instead, as students furthered discussed, to minimize the feelings of shame and guilt: 'We, Americans ignore or forgot about how our nation was built', and people often 'pretend that it was like four hundred years ago that everything stopped happening.' Students pointed out, however, how recent in reality this history is, and how its repercussions continue until today. As one Latina student sarcastically put it: 
People act like that was in fifteen hundred that Martin Luther King was alive...I'm like no, like our mommies and daddies were probably, you know, in diapers around that age.... All this stuff it's not that far away. It really isn't.

Despite the different defense mechanisms in which the United States engages, students believed the country needs to acknowledge and redress the racial injustice that has been a major part of its history and which continues into the present. Students hoped the U.S. education would be more truthful because 'knowing the full story' is the first step towards addressing the topic of racial oppression. Students believed that educational settings should provide the space for meaningful conversations about race and racism, and they wondered how the learning they experienced in Ghana could be incorporated into regular U.S. classrooms. Although students recognized that talking about topics such as racism and slavery will be difficult, as one Latina student put it, 'those are the things that we need to be talking about.... Someone needs to be talking about it.'

The transformative experiences students went through, and especially the awakening to the past and present racial realities many of them were oblivious to, motivated them to become anti-racism advocates. As White student explained in her journal: 'I realized that I have been able to successfully work past my own White fragility in order to not only be a better learner and listener, but also to be a better ally and advocate.' Students gained a new urgency to speak up and challenge racist remarks and jokes in their circle of friends and felt a general responsibility to educate others in the United States about what they learned in Ghana. Some questioned their 'daily participation' in the maintenance of structural racism on both the global and local levels, through, for example, ignorance and inaction about unfair trade with African countries and institutional racism in the United States. 


\section{Discussion}

Our findings implicate critical shortcoming in the way students in the United States are taught about the national and world history that reveals the racial violence and injustice against African descent people and other racial and ethnic minority groups. As participants described, they were shocked to discover how little they knew about the history of colonialism and slavery and their continued impact on the United States and Africa. The most eye-opening and emotional experience for students was the visit to the slave castles and learning about the magnitude and gravity of the violence and injustice against Africans and people of African descent. Students were able to make connections between the past and present realities of racial oppression and different forms of structural racism. Students reported feeling very frustrated with the U.S. education system, which did not teach them nearly enough about the tragic history of racial oppression and the suffering of the people of African descent in the United States and globally. Finally, they stressed the need for change and healing from the past and present racial oppression through a more truthful education on the topic, an honest dialogue about racism, and anti-racism advocacy.

The U.S. national culture of silence and dismissal of historical truths of racial injustice and oppression (Trouillot 1995) does not allow new generations to learn from the past and to avoid committing the same mistakes. It is tragic that James Baldwin's words written in 1965 are

also relevant today: 'The fact that Americans, White Americans, have not yet been able to do this - to face their history, to change their lives - hideously menaces this country. Indeed, it menaces the entire world' (175). We argue that the way education about historical and present racial realities is structured in the United States is motivated by what Lowe (1996) calls 'the ontology of forgetting' (as cited in Pon 2009, 59). Referring to the genocide of Aboriginal people in what 
is today Canada, Pon $(2009,66)$ explains that 'this present ontology of liberal democratic nationstates such as the United States and Canada involves forgetting the history of White supremacy, racism, and Western imperial projects that proved central to the states' formation and ascendancy.' The 'ontology of forgetting' in turn leads to a lack of education or miseducation about the problematic history of the United States and its current repercussions and perpetuation.

The study's findings further speak to the importance of building on critical race theory in educational settings, and particularly the urgency to incorporate the unique voice of color (Delgado and Stefancic 2001) into the curricula. As the students who went to Ghana discovered first hand, the history of racial and ethnic minority groups, here particularly the history of African descent people, has been silenced. By becoming exposed to a historical counternarrative, the students gained an understanding of the current racial dynamics and the needed anti-racism work. It is important to remember, however, that if White professors and students are unprepared or unwilling to examine the history of White supremacy following a storytelling or counterstorytelling experience, it can cause great harm to the storyteller and students of color who must endure the double trauma of not only the historic racial oppression but also the wound of having issues of race taken up unproductively in the classroom. Nevertheless, if conducted properly storytelling and counter-storytelling can be a 'cure for silencing' (Delgado and Stefancic 2001, 49) and a tool 'to bridge gaps of understanding and empathy' (Pulliam 2017, 420), crucial for an effective dialogue and action against racism. As DiAngelo (2018) emphasized, interrupting racism, 'so deeply woven into the fabric of our society' (87), requires a lifelong effort and commitment, particularly for White people who are the beneficiaries of racial inequalities. The racial awakening that the students experienced in Ghana motivated them to start this lifelong process by expanding their historical knowledge and striving to become anti-racism advocates. 


\section{Limitations}

The purposive sampling methods and focus on students from two universities only, both located in the southern United States, limit our ability to generalize the results beyond the study participants. Moreover, the study design was not intended to compare student perspectives across college majors. Most of the students in the sample were social work majors, and it is possible that the perspectives of students from other majors or even within the same majors may vary from those described here. In addition, our findings cannot speak to differences in students' prior knowledge about the history of slavery and racism depending on their college major but show the gaps in student history knowledge in general terms. Finally, the study did not compare the student learning across racial/ethnic groups because the study's sample was predominantly White and Latino. Specifically, the study did not capture all aspects of how the experiences and perspectives of Black/African American students may be unique from students of other racial/ethnic backgrounds.

\section{Implications}

Despite these limitations, the study provided several insights into the current education students are offered in the United States regarding the history of colonialism, slavery, and racism. First, the study revealed the urgency to change the way this painful history is addressed in the U.S. educational institutions. By fully exposing students to the dehumanization of people of African descent, as well as other racial and ethnic minorities, which has been a part of the U.S. history from its very beginning, educators can significantly contribute to creating more conscious, antiracist, and politically active U.S. citizens. This, in turn, may contribute to breaking the cycle of the racial oppression. Additionally, as Daniel $(2008,33)$ points out 'Students should be 
introduced not only to the pain and suffering of oppressed peoples but also to the victories achieved by various struggles for liberation.'

As the study shows, college students have significant gaps in knowledge and understanding the history of racial dynamics. It is thus important that higher education institutions do not assume that students come into college with a sufficient understanding of the history of slavery and racial oppression (Olwell 2001). In addition to a radical shift in high school education, institutions of higher education should ensure that young people have a solid understanding of the historical and present racial oppression. Initiatives such as the Center for the Study of Slavery and Justice at Brown University (Brown University 2018) offers one way to address this gap in higher education by drawing attention to the significance of slavery.

The findings of the study also point to the need for reevaluating the pedagogical methods when teaching about topics such as slavery or racism. Contradictory to the current education that avoids controversy and silences the past (Trouillot 1995), teaching of history of racial oppression needs to be authentic and courageous; it needs to name the dehumanizing historical facts for what they are. Emotional detachment and the sole focus on cognitive learning, prevalent in U.S. education, do not allow for the necessary depth of understanding of the experiences of historically excluded racial and ethnic groups. Existing literature suggests that teaching and learning about racial oppression should incorporate the experiential and affective domains (Cramer, Ryosho, and Nguyen 2012; Deepak and Biggs 2011; Loya and Cuevas 2010). Experiential learning requires students' active involvement with their learning process, and it moves students from just learning about a subject matter to actually understanding it (Weaver 1998). Affective learning taps into students' feelings and helps them develop empathy towards others (Fox 1983). For example, Deepak and Biggs (2011) found that students who learned about 
racism through images, music, and personal stories experienced deep emotional responses such as anger and sadness. This 'emotional connection to the material' (50) helped them be more engaged in the learning process and understand racism in more depth. Consistent with this literature, the learning that took place for the study participants was significantly enhanced by the visit to the slave castles and by being deeply emotionally moved by those experiences.

Despite the 'pedagogical tensions and struggles' (Daniel 2011, 250) inherent in teaching about historical and present racial oppression, "professors should be prepared to "go there", (Deepak, Rountree, and Scott 2015, 116) to help students fully comprehend and internalize the experiences of oppression and dehumanization of racial and ethnic minority groups. Instructors need to work towards transforming unproductive emotions such as denial, defensiveness, anger, guilt, or shame, which are common, particularly among White students, when the topic of race and racism is brought up (DiAngelo 2018). It is likely that many professors, particularly White ones or those at Predominately White Institutions (PWIs), may be unprepared to undertake the critical race curriculum, and they need to go through this learning process themselves first. Educators therefore need to be intentional about seeking professional development opportunities, such as the Undoing Racism trainings (The People's Institute for Survival and Beyond, 2018), to understand and enhance their own conceptual and emotional preparedness for undertaking critical dialogue around racism, slavery, and colonialism. Professors should also consider replacing or complementing traditional teaching methods such as lectures and PowerPoint presentations with methods that have been found effective in teaching about racism, inequality, and social justice including antiracist pedagogy (Blakeney 2005; Kandaswamy 2007), intergroup dialogue (Dessel and Rodenborg 2017; Nagda and Gurin 2007), and an Afrocentric culturally informed praxis (King and Swartz 2015; King et al. 2014). Storytelling and counter storytelling, 
which bring the silenced narratives of people of color to the surface (Ladson-Billings 1998), novels, films, runaway ads, spirituals, and material culture (Jay and Lyerly 2016) can all serve as powerful tools of awakening the affective aspect of student learning. Future research should further examine the role of emotional and experiential learning in opening a dialogue on race and racism and motivating student to become anti-racism advocates.

\section{Conclusion}

It seems essential for the present and future racial relations that the United States acknowledges and heals from the historical trauma inflicted upon the racial and ethnic minority people and strives for racial equity. Through anti-racist education that includes a true presentation of the U.S. history, educators can create a generation of young people who are willing to have an open an honest dialogue about past and present racial injustice and seek equity, healing, and reconciliation. As Spencer $(2008,99)$ phrased it in his reflections on power, privilege, and oppression:

The most painful thing about racism is its invalidation, even more so than the incident itself. I hope for reconciliation, but I recall that reconciliation requires 'truth.' We are just beginning to learn about the truth of racism in this country and, thus, are still far from reconciliation.

Facing and learning from the history can thus be the starting point towards equity, healing, and reconciliation. Authentic history education can orient the future generations which come through the doors of the U.S. schools and universities, to 'where they are, but more importantly, what they must be' (John Henrik Clarke, as cited in Cornell University Library 2016).

\section{Disclosure statement}

No potential conflict of interest was reported by the authors. 


\section{References}

Adams, G., Edkins, V., Lacka, D., Pickett, K. M., and Cheryan, S. 2008. “Teaching about Racism: Pernicious Implications of the Standard Portrayal.” Basic and Applied Social Psychology 30(4): 349-361. doi:10.1080/01973530802502309

Baldwin, J. 1966. "Unnameable Objects, Unspeakable Crimes." In The White Problem in America, edited by the editors of Ebony, 173-181. Chicago, IL: Johnson. Publishing Company.

Bazeley, P. 2007. Qualitative Data Analysis with NVivo. London: Sage Publications Ltd.

Bell, D. 1992. And We Are Not Saved: The Elusive Quest for Racial Justice. New York: Basic Books.

Blakeney, A. M. 2005. “Antiracist Pedagogy: Definition, Theory, Purpose and Professional Development.” Journal of Curriculum \& Pedagogy 2(1): 119-132. doi: $10.1080 / 15505170.2005 .10411532$

Boateng, A., and Thompson, A. M. 2013. "Study Abroad Ghana: An International Experiential Learning." Journal of Social Work Education 49(4): 701-715. doi:

$10.1080 / 10437797.2013 .812897$

Braun, V., and Clarke, V. 2006. "Using Thematic Analysis in Psychology.” Qualitative Research in Psychology 3(2): 77-101. doi:10.1191/1478088706qp063oa

Brown University 2018. The Center for the Study of Slavery and Justice (CSSJ). Accessed December 15 2018. https://www.brown.edu/initiatives/slavery-and-justice/ Cornell University Library 2016. John Henrik Clarke Bibliography: Home. Accessed November 25 2018. http://guides.library.cornell.edu/clarke 
Cramer, E. P., Ryosho, N., and Nguyen, P. V. 2012. 'Using Experiential Exercises to Teach about Diversity, Oppression, and Social Justice.” Journal of Teaching in Social Work 32(1): 1-13. doi:10.1080/08841233.2012.637463

Creswell, J. W. 2013. Qualitative Inquiry and Research Design: Choosing among Five Approaches (3rd Edition). Thousand Oaks: Sage Publications, Inc.

Daniel, C. 2008. "From Liberal Pluralism to Critical Multiculturalism: The Need for a Paradigm Shift in Multicultural Social Work Practice in the United States.” Journal of Progressive Human Services 19(1): 19-38. doi:10.1080/10428230802070215

Daniel, C. 2011. “Lessons Learned: Pedagogical Tensions and Struggles with Instruction on Multiculturalism in Social Work Education Programs.” Social Work Education 30(3): 250-265. doi:10.1080/02615471003789829

Das, C., and Anand, J. C. 2014. "Strategies for Critical Reflection in International Contexts for Social Work Students.” International Social Work 57(2): 109-120. doi:10.1177/0020872812443693

Deepak, A. C., and Biggs, M. J. G. 2011. "Intimate Technology: A Tool for Teaching AntiRacism in Social Work Education.” Journal of Ethnic \& Cultural Diversity in Social Work 20(1): 39-56. doi:10.1080/15313204.2011.545944

Deepak, A. C., Rountree, M. A., and Scott, J. 2015. "Delivering Diversity and Social Justice in Social Work Education: The Power of Context.” Journal of Progressive Human Services 26(2): 107-125. doi:10.1080/10428232.2015.1017909

Delgado, R., and Stefancic, J. 2001. Critical Race Theory: An Introduction. New York: New York University Press. 
Dessel, A. B., and Rodenborg, N. 2017. “An Evaluation of Intergroup Dialogue Pedagogy: Addressing Segregation and Developing Cultural Competency." Journal of Social Work Education 53(2): 222-239. doi:10.1080/10437797.2016.1246269

DiAngelo, R. 2018. White Fragility: Why It's so Hard for White People to Talk about Racism. Boston: Beacon Press.

Emerson, R. M., Fretz, R. I., and Shaw, L. L. 2011. Writing Ethnographic Fieldnotes (2nd ed.). Chicago: The University of Chicago Press.

Fox, J. R. 1983. “Affective Learning in Racism Courses with an Experiential Component.” Journal of Education for Social Work 19(3): 69-76. https://www.jstor.org/stable/41350653

George, M. P., and Williams, D. M. 2018. “Teaching about Race and Social Action by 'Digging Up the Past': the Mary Turner Project.” Race Ethnicity and Education 21(3): 319-334. doi:10.1080/13613324.2017.1328593

Grant, C. A. 2011. "Escaping Devil's Island: Confronting Racism, Learning History.” Race Ethnicity and Education 14(1): 33-49. doi:10.1080/13613324.2011.531979

Grbich, C. 2012. Qualitative Data Analysis: An Introduction. Los Angeles: Sage Publications, Inc.

Guest, G., MacQueen, K. M., and Namey, E. E. 2012. Applied Thematic Analysis. Thousand Oaks: Sage Publications, Inc.

Jay, B., and Lyerly, C. L. 2016. Understanding and Teaching American Slavery. Madison: The University of Wisconsin Press.

Lofland, J., Snow, D., Anderson, L., and Lofland, L.H. 2006. Analyzing Social Settings: A Guide to Qualitative Observation and Analysis (4 ${ }^{\text {th }}$ edition). Belmont: Wadsworth/Thompson. 
Kandaswamy, P. 2007. "Beyond Colorblindness and Multiculturalism: Rethinking Anti-Racist Pedagogy in the University Classroom." The Radical Teacher 80(80): 6-11. http://www.jstor.org/stable/20710420

Kerr, C. Nixon, A. and Wild, D. 2010. "Assessing and Demonstrating Data Saturation in Qualitative Inquiry Supporting Patient-Reported Outcomes Research.” Expert Review of Pharmacoeconomics \& Outcomes Research 10(3): 269-281. doi:10.1586/erp.10.30

Khan, N. M. 2013. "Slavery in Two Nations: Examining the Presentation of Slavery in Secondary U.S. and Brazilian History Textbooks.” PhD diss., Emory University.

King, L. J. 2016. “Teaching Black History as a Racial Literacy Project.” Race Ethnicity and Education 19(6): 1303-1318. doi:10.1080/13613324.2016.1150822

King, J. E., and Swartz, E. E. 2015. The Afrocentric Praxis of Teaching for Freedom: Connecting Culture to Learning. New York: Routledge.

King, J. E., Swartz, E. E., Campbell, L., Lemons-Smith, S., and López, E. 2014. 'Re-membering' History in Student and Teacher Learning: An Afrocentric Culturally Informed Praxis. New York: Routledge.

Kolchin, P. 1998. "Slavery in the United States Survey Textbooks.” Journal of American History 84(4): 1425-1438. doi: 10.2307/2568089

Ladson-Billings, G. 1998. "Just what is Critical Race Theory and what's it Doing in a Nice Field Like Education?” International Journal of Qualitative Studies in Education 11(1): 7-24. doi:10.1080/095183998236863

Ladson-Billings, G. 2005. “The Evolving Role of Critical Race Theory in Educational Scholarship." Race Ethnicity and Education 8(1): 115-119. doi:10.1080/1361332052000341024 
Ledesma, M. C., and Calderón, D. 2015. “Critical Race Theory in Education: A Review of Past Literature and a Look to the Future." Qualitative Inquiry 21: 206-222. doi:10.1177/1077800414557825

Lincoln, Y. S., Guba, E. G. 1985. Naturalistic Inquiry. Beverly Hills: Sage Publications, Inc. LeCompte, M. D., and Schensul, J. J. 1999. Analyzing and Interpreting Ethnographic Data. Walnut Creek: Altamira.

Levine, M. 2009. “Transforming Experiences: Nursing Education and International Immersion Programs.” Journal of Professional Nursing 25(3): 156-169. https://doi.org/10.1016/j.profnurs.2009.01.001

Loewen, J. W. 2007. Lies My Teacher Told Me: Everything Your American History Textbook Got Wrong (Touchstone trade pbk. ed.). New York: Simon \& Schuster.

Loya, M. A., and Cuevas, M. 2010. “Teaching Racism: Using Experiential Learning to Challenge the Status Quo.” Journal of Teaching in Social Work 30(3): 288-299. doi:http://dx.doi.org/10.1080/08841233.2010.497130

Mapp, S. C. 2012. "Effect of Short-Term Study Abroad Programs on Students' Cultural Adaptability.” Journal of Social Work Education 48(4): 727-737. doi:10.5175/JSWE.2012.201100103

Marx, S., and Pray, L. 2011. "Living and Learning in Mexico: Developing Empathy for English Language Learners Through Study Abroad.” Race Ethnicity and Education 14(4): $507-$ 535. doi:10.1080/13613324.2011.558894

Meyrick, J. 2006. "What is Good Qualitative Research?: A First Step towards a Comprehensive Approach to Judging Rigour/Quality.” Journal of Health Psychology 11(5): 799-808. doi:10.1177/1359105306066643 
Nagda, B. A., and Gurin, P. 2007. "Intergroup Dialogue: A Critical-Dialogic Approach to Learning about Difference, Inequality, and Social Justice.” New Directions for Teaching and Learning 111: 35-45. doi:10.1002/t1.284

Olwell, R. 2001. "New Views of Slavery: Using Recent Historical Work to Promote Critical Thinking about the 'Peculiar Institution.'” The History Teacher 34(4): 459-469. doi:10.2307/3054199

The People's Institute for Survival and Beyond. 2018. “Undoing Racism.” Retrieved from http://www.pisab.org/

Pon, G. 2009. “Cultural Competency as New Racism: An Ontology of Forgetting.” Journal of Progressive Human Services 20(1): 59-71. doi:10.1080/10428230902871173

Pulliam, R. M. (2017). "Practical Application of Critical Race Theory: A Social Justice Course Design.” Journal of Social Work Education 53(3): 414-423. doi:10.1080/10437797.2016.1275896

Reisch, M. 1988. “The Uses of History in Teaching Social Work.” Journal of Teaching in Social Work 2(1): 3-16. doi:10.1300/J067v02n01_02

Schuldberg, J., Fox, N. S., Jones, C. A., Hunter, P., Mechard, M. Stratton, M. 2012. "Same, Same but Different: The Development of Cultural Humility Through an International Volunteer Experience.” International Journal of Humanities and Social Science 2(17): 17-30. http://www.ijhssnet.com/journals/Vol_2_No_17_September_2012/3.pdf

Smith, L. 1998. "Facing Slavery and Ourselves: Are We Ready?.” Social Education 62(6): 329332. https://eric.ed.gov/?id=EJ582734

Southern Poverty Law Center [SPLC]. 2018. Teaching the Hard History of American Slavery. https://www.splcenter.org/sites/default/files/tt_hard_history_american_slavery.pdf 
Spencer, M. S. 2008. “A Social Worker's Reflections on Power, Privilege, and Oppression.” Social Work 53(2): 99-101. doi:10.1093/sw/53.2.99

Tate, W. F. 1997. "Critical Race Theory and Education: History, Theory, and Implications.” Review of Research in Education 22: 195-247. doi: 10.2307/1167376

Tatum, B. D. 1999. “It's Not so Black \& White.” Instructor-Primary 108(5): 29-31. http://connection.ebscohost.com/c/articles/1429093/not-so-black-white

Trouillot, M. 1995. Silencing the Past: Power and the Production of History. Boston: Beacon Press.

Tuckett, A. G. 2005. "Part II. Rigour in Qualitative Research: Complexities and Solutions." Nurse Researcher 13(1): 29-42. doi: 10.7748/nr2005.07.13.1.29.c5998

VeLure Roholt, R., and Fisher, C. 2013. "Expect the Unexpected: International Short-Term Study Course Pedagogies and Practices.” Journal of Social Work Education 49(1): 48-65. doi:10.1080/10437797.2013.755416

Weaver, H. N. 1998. "Teaching Cultural Competence: Application of Experiential Learning Techniques in Social Work.” Journal of Teaching in Social Work 17(1-2): 65-79. doi:10.1300/J067v17n01_06

Yosso, T. J. 2002. “Toward a Critical Race Curriculum.” Equity \& Excellence in Education 35: 93-107. doi:10.1080/713845283 